\title{
Prof dr L J S Steenkamp: 'n Oorsig van sy lewe en werk
}

\author{
P J van der Merwe
}

Departement Godsdiens- en Sendingwetenskap (Afd A)

Universiteit van Pretoria

\section{Abstract \\ Prof Dr L J S Steenkamp: A review of his life and career}

Prof Lourens fohames Stephanus Steenkamp retired on medical grounds from his teaching post at the Faculty of Theology (Section A), Unwersity of Pretoria, on 31 March 1999. This article contains some biographical notes and a brief review of his careen Lourens Steenkanp's career th the ministy of the Nederdulsch Henvornde Kerk (NHK) started in 1973 in a small fown on the Mpunalanga platheland. In 1087 he received the DPhll degree of the University of Pretoria. The tile of his thesis was "Aristotle's concept of God". His career took a new turn in 1989 when he was appointed director of the NHK's Institure for the Training of Office Bearers and Church Members and head of the Centre for Theological Research and Instruction (STNT) of the Faculty of Theology (Section A), Universily of Pretoria. In 1994 he moved over to the Faculy as fill-time organiser of the centre's programmes and part time lecturer in Philosophy of Retigion. His nain interests were two-folds theology and educationd policy matters. His contribution in bolh of these fldds is discussied and reviewed.

\section{OP PAD NA DIE BEDIENING}

Lourens Johannes Stephanus Steenkamp is op 7 Augustus 1946 in die Bronkhorstspruitse distrik gebore en 'n klompie weke later in die Hervormde 'Kerk van Bronkhorstspruit gedoop. Sy ouers het op daardie stadium op die plaas Renosterpoort gewoon. Hy groei in 'n plattelandse Afrikanerhuis op met ouers wat alles feil gehad het vir die Nederduitsch Hervormde Kerk. Hy woon die Laerskool Marble Hall by en nóg later die Hoërskool 
Ben Viljoen, Groblersdal. Reeds op laerskool kom sy leierseienskappe, naas sy skolastiese vermoë, na vore. Hy word aangewys as onderhoofseun. Op hoërskool word hy later as hoofseun benoem. Hy slaag matriek in 1964 met onderskeidings in Wiskunde, Rekeningkunde en Skei- en Natuurwetenskap.

Hy verwerf ' $n$ beurs van die destydse SAS \& H wat hom in staat stel om in 1965 by die Universiteit van Stellenbosch in te skryf vir die graad BCom (Vervoerekonomie). So gebeur dit dat hierdie boerseun uit die Groblerdalse distrik op Stellenbosch beland. Sy rugbytalent sorg daarvoor dat hy by sy aankoms vir Maties onder-19 en die daaropvolgende jaar vir Maties onder-20 speel. Op akademiese front gaan dit ook goed. Hy voltooi twee kursusjare suksesvol, maar soos die tyd aangestap het, het dit vir hom duidelik geword dat hy hom nie met 'n loopbaan in bestuurswese sou kon versoen nie. Tegelykertyd het die drang om predikant te word, al sterker geword. Daarom verlaat hy Stellenbosch aan die einde van 1966 en skryf hy aan die begin van 1967 by die Universiteit van Pretoria in vir die BA (met die oog op BD).

Ten einde sy beursverpligtings na te kom, werk hy 'n jaar lank vir die Spoorweë. In 1968 begin hy by Agricura werk. Gedurende sy hele verdere studietyd (tot einde 1972) studeer hy deeltyds. In hierdie tyd blyk iets van sy praktiese aanleg, omdat hy tydens sy dienstermyn by Agricura saam met 'n kollega 'n apparaat ontwikkel wåarmee die toediening van berokingsmiddel teen aalwurm met meganiese akkerbewerking gekombineer kon word. Dit het vir die firma goeie verkope meegebring, maar het ook veroorsaak dat daar groot druk op hom gekom het om die teologiese studie te laat vaar ten gunste van 'n loopbaan by Agricura. Hy het hom egter nie laat ompraat nie en met sy teologiese studie volhard.

Teen hierdie agtergrond en met sy vorige studierigting in ag geneem val dit enigsins vreemd op dat Lourens gedurende sy BA-studie 'n groot belangstelling in Wysbegeerte ontwikkel. Hy voltooi die BA in 1969. Sy hoofvakke was Wysbegeerte en Sielkunde. In 1970 skryf hy in vir die BD-studie. Gelyktydig met BD skryf hy in 1970 ook in vir BA Hons in Wysbegeerte wat hy dieselfde jaar voltooi.

Die jaar 1971 was 'n hoogtepunt, want toe het hy in die huwelik getree met Duveen Naudé van Menlo Park, Pretoria. Prof P S Dreyer het die huwelik bevestig. 
Duveen is die dogter van die bekende klassikus, prof C P T Naudé, jare lank verbonde aan Unisa. Uit hierdie gelukkige huwelik is uiteindelik vyf kinders gebore.

Gedurende sy finale studiejaar dien hy ook as praeses van Van der Hoff-Teologiese Vereniging.

\section{PREDIKANT EN DOSENT}

Lourens Steenkamp het in 'n tyd studeer toe daar 'n tekort aan predikante in die Nederduitsch Hervormde Kerk was. Daarom het hy die kommer oor 'n beroep vrygespring wat die lot van hedendaagse teologiese studente is. Daar het egter 'n ander soort skaduwee oor sy laaste studiejaar gehang. Sy vader het terminale maagkanker ontwikkel. (Tans is sy moeder ernstig siek, ook aan kanker).

Lourens ontvang na legitimasie 'n beroep na die gemeente Ogies wat hy ook aanvaar. Die ordening en ontvangs moes egter uitgestel word, omdat sy vader al sieker geword het en trouens beswyk het op dieselfde dag wat aanvanklik vir die ordening bepaal is. Die ordening en ontvangs het uiteindelik op 27 Januarie 1973 plaasgevind. So is 'n hoogtepunt waarna jare lank uitgesien is, versomber, maar dit was nogtans die begin van 'n gelukkige en suksesvolle loopbaan as gemeentepredikant.

$\mathrm{Na}$ aangename jare in Ogies aanvaar hy in 1977 'n beroep na die gemeente Villieria. Daar dien hy en Duveen vir baie jare as pastoriepaar en sluit hulle ook 'n hegte band met die oostelike-Mootgemeenskap wat tot vandag toe duur. In dieselfde periode dien hy ook vir 'n tydlank as ringsvoorsitter van die Ring van Noordelike Pretoria.. Hulle band met die Mootgemeenskap kom ook na vore in sy betrokkenheid by die bestuursliggame van verskeie skole, in baie gevalle as voorsitter. Tans is hy nog betrokke by die bestuursliggame van die Laerskool Voorpos, Hoërskool Oosmoot en Hoër Tegniese Skool John Vorster.

Intussen het hy sy nagraadse studie in Wysbegeerte voortgesit en in 1983 behaal hy sy meestersgraad met lof. Die titel van sy verhandeling was: "Die ontwerp van 'n metafisiese orde by die vroeë Griekse kosmoloë." In 1987 behaal hy die DPhil, ook met lof. Die titel van sy proefskrif was: "Die godsbegrip by Aristoteles." Beide verhandeling en proefskrif is onder die leiding van prof P S Dreyer voltooi. 
'n Nuwe fase in sy kerklike loopbaan breek in 1989 aan wanneer hy as 'n direkteur van die NHK se Kerklike Instituut vir die Toerusting van Ampsdraers en Lid-mate (Kital) aangestel word. In Mei van dieselfde jaar volg hy prof J H Koekemoer op as hoofdirekteur van Kital en in Oktober 1989 word hy ingevolge die destydse reëling tussen die Nederduitsch Hervormde Kerk en die Universiteit van Pretoria hoogleraar in die Fakulteit Teologie (Afdeling A) met opdrag direkteur van die Sentrum vir Voortgesette Teologiese Toerusting (SVTT).

In hierdie tyd verskyn verskeie publikasies by Kital-Uitgewers as gevolg van sy inisiatief, waaronder die bekende Lees en lewe-Bybelstudiereeks. Ander bekende publikasies wat hy gefasiliteer het, was Van Wyk, W C (red) 1991, Joodse bure; Van Aarde, A G \& Pelser, G M M 1994, Corpus Paulinum: Inleiding en teologie; Van Aarde, A G 1994, Kultuurhistoriese agtergrond van die Nuwe Testament: Die eerste-eeuse Mediterreense sosiale wêreld; en Van der Westhuizen, H G 1994, Herder van Angola. Hy dien ook vir baie jare as redakteur van die Bybelse Dagboek. In 1992 gee hy ook Dagboek vir ' $n$ vrou uit. Gedurende sy dienstydperk by Kital neem hy verskeie kere waar as redakteur van Die Hervormer en verskyn etlike nommers onder sy leiding.

Gedurende sy kerklike loopbaan het hy in meer as een sinodale rade en kommissies gedien. 'n Vinnige oorsig bring die volgende aan die lig: die Algemene Diakonale Raad, die Raad vir Kategese, die Kommissie van Ondersoek na Bedieningstrukture, die redaksie van Die Hervormer en die Raad vir Opvoeding en Onderwys.

Naas kerksake het hy oor jare heen 'n diepgaande belangstelling in en groot kundigheid oor onderwyssake ontwikkel. Daarom verbaas dit nie dat hy by die Interkerklike Kommissie vir Opvoeding en Onderwys (IKOO) se dagbestuur betrek is en dat hy tans nog op die sentrale regering se Nasionale Onderwysforum, asook die Afrikaanse Eenheidskomitee vir Onderwys dien nie.

Met die rasionalisasie en herstrukturering van Kital skuif prof Steenkamp in 1994 in die geheel oor na die SVTT (wat later verander na die Sentrum vir Teologiese Navorsing en Toerusting - STNT). Hy aanvaar 'n wye spektrum van verantwoordelikhede wat met die funksionering van die STNT verband hou. Later ontvang hy ook die taak om Ensiklopedie in die Departement Dogmatiek en Christelike Etiek en die vak Godsdiensfilosofie in die Departement Godsdiens- en Sendingwetenskap (A) te doseer, asook ver- 
skeie ander doseerpligte in laasgenoemde departement. Nóg later word hy ook betrek by die onderrig van die Hervormde Teologiese Opleiding te Klipdrif. In hierdie diverse hoedanighede tree hy op totdat hy gedurende die tweede helfte van 1998 aansoek om siektepensioen doen en met siekteverlof gaan. Sy aansoek word toegestaan en hy tree op 31 Maart 1999 uit met siektepensioen.

\section{AS TEOLOOG EN ONDERWYSMAN}

Lourens Steenkamp se bydrae kan oor 'n wye terrein gehuldig word, byvoorbeeld sy betrokkenheid by kultuur- en gemeenskapsaangeleenthede, sy betrokkenheid by onderwyssake, as kerkman en as akademikus. Ons bepaal ons egter by sy betrokkenheid by en visie ten opsigte van die onderwys, teologie en voortgesette predikantsopleiding. As bron daarvoor dien twee onderhoude wat deur skrywer met hom gevoer is.

\section{OPVOEDING EN ONDERWYS}

Sy belangstelling op die terrein van opvoeding en onderwys sentreer, soos begryp kan word, hoofsaaklik rondom filosofiese en beleidsake. 'n Verdere saak wat hom interesseer, is die uitdagings wat veranderende paradigmas vir die onderwys inhou.

Sy belangstelling in onderwysbeleid gaan terug na noue persoonlike kontak met die voormalige rektor van die Universiteit van Pretoria, prof C H Rautenbach, wat op sigself 'n "wandelende ensiklopedie" in sake die historiese en kulturele agtergronde van Suid-Afrikaanse onderwysbeleidskwessies en -beginsels was en wat hom in die besonder besig gehou het met die kerklike belang by en perspektief op die hele saak van opvoeding en onderwys. Prof Rautenbach was 'n ywerige leser van die kontinentale en veral Nederlandse literatuur oor onderwysdenke. Hy het dit ook sy plig geag om hierdie perspektief aan die woord te stel in opposisie met die Engelse en Amerikaanse denke wat toenemend by Suid-Afrikaanse beleidmakers begin figureer het. Lourens het dus op indirekte wyse heelwat Europese invloed ondergaan.

Gedurende die tagtigerjare verskyn die sogenaamde De Lange-verslag oor die onderwys en dit stimuleer nuwe Afrikanerdenke oor opvoeding en onderwys. Lourens raak as gevolg van sy betrokkenheid by skoolbestuursliggame betrokke by hierdie gesprek. Hy leer bekende persone goed ken, soos die bekende dr Gerrit Viljoen, voorma- 
lige minister van onderwys, prof Henry Stone (Unisa) en die genoemde prof Pieter de Lange, op daardie stadium rektor van RAU. Die vorming wat hy in die proses ondergaan het, het hom 'n ondersteuner gemaak van die na-oorlogse en post-moderne denke dat onderwys en opvoeding nie 'n saak van die sentrale owerheid alleen is nie, maar dat plaaslike owerheidstrukture en veral plaaslike gemeenskappe 'n beduidende rol daarin te speel het.

Die vinnige opkoms en sukses van sogenaamde model C-skole wat op die beginsel van gemeenskapsondersteunde onderwys berus, het bewys dat hierdie gedagtegang nie alleen realisties is nie, maar ook die angewese rigting is om te gaan. Baie gemeenskappe het die geleenthede van die destydse nuwe onderwysbeleid aangegryp om hulle skole binne 'n relatief kort periode sterk uit te bou. Nuwe bronne van finansiële ondersteuning en kundigheid is in die gemeenskappe geïdentifiseer en ontwikkel. Selfs kritici moes toegee dat die stelsel gemeenskappe betrokke gekry het soos min vorige stelsels kon.

Dit het hom ook tot die oortuiging gebring dat die kerk se onderwysverantwoordelikheid nie in vennootskap met die staat op sentrale vlak alleen uitgeleef kan word nie, maar dat die plaaslike kerk en spesifiek lidmate met kinders op skool, 'n onontkombare verantwoordelikheid teenoor onderwys en opvoeding in die gemeenskap het. Miskien is dit juis op laasgenoemde terrein waar die kerk (by wyse van gelowige ouers) op die mees sinvolle wyse kan saamwerk en medeverantwoordelikheid kan aanvaar.

Die onderwysbeleid van die huidige regering met 'n sterk sentraliserende neiging is ' $n$ terugwaartse beweging na 'n vorige en agterhaalde beleid, en daarom ' $n$ hartseersaak. Hoewel dit inpas by die regering se ideologie van sentrale beheer, beweeg dit teen die stroom in van Westerse en post-moderne onderwysdenke. Boonop sal die filosofiese droom en visie van ' $n$ Afrika-renaissance slegs in 'n beperkte mate sentraal van bo gerig en bestuur kan word. Indien dit nie die geleentheid kry om op voetsoolvlak, dit wil sê vanuit die gemeenskappe, te groei en gevoed te word nie, sal dit blote politieke retoriek, of op die beste, sentrale ideologie bly.

Die huidige Suid-Afrikaanse regering strewe daarna dat kerke en tradisionele leiers vennote van die regering sal word in 'n nuwe kampanje van opvoeding en moraliteitsopbou. Dit plaas baie kerke in 'n dilemma: enersyds wil hulle nie ingetrek word in 
'n nuwe burgerlik-godsdienstige omhelsing nie, maar andersyds wil hulle nie geostraseer word nie.

In hierdie omstandighede vind prof Steenkamp nogtans 'n tragiese gebrek aan visie en die voer van 'n verwarrende debat in die Hervormde Kerk oor die kerk se taak ten opsigte van opvoeding en onderwys in die huidige konteks. Aan die een kant is daar diegene wat meen dat die kerk sigself heeltemal van die onderwys moet distansieer en dit aan die lidmate van die kerk in hulle burgerlike hoedanigheid moet oorlaat. Aan die ander kant is daar diegene wat die kerk so ver wil kry om met kerkskole te begin en die openbare skoolstelsel die rug te keer. Sulke ekstreme posisies is nie alleen in stryd met die tradisie van die NHK nie, maar ook onrealisties en moontlik onverantwoordelik.

So ' $n$ uitspraak moet gesien word teen die agtergrond van die regeringsplan om onderwys verplig te maak tot graad 9 (ou standerd 7) en die moontlikheid dat onderwys in grade 10-12 volledig deur ouers bekostig sal moet word. Indien laasgenoemde werklikheid word, sal dit beteken dat 'n beduidende persentasie jongmense op die ouderdom van 14-15 jaar van formele skoolonderrig afskeid sal neem. Hulle sal geen ander keuse hê as om die arbeidsmark te betree en aan die invloede en werklikhede van die grootmenswêreld blootgestel te word nie.

Buitendien word voorsien dat die persentasie jongmense wat hulle opleiding aan tegniese kolleges en met indiensopleiding opdoen, in die toekoms drasties sal toeneem, terwyl 'n skerp afname in die persentasie universiteitstudente voorsien word. Sulke werkende jongmense is grotendeels op hulleself aangewese, dit wil sê sonder ouerbegeleiding. Terwyl daar by hulle 'n groot behoefte aan leiding en vorming, dit wil sê ook aan kontak met die kerk bestaan, is die kanse goed dat dit lank gaan neem voordat die kerk hierdie behoefte gaan raaksien en iets daaraan gaan doen. Die stelling kan trouens gemaak word dat daar reeds 'n geslag jongmense ontwikkel het wat as post-kerklik beskryf kan word. Onder druk van finansiële omstandighede is die NHK besig om op baie fronte terug te val, terwyl verskeie kerkgroepe wat nie as tradisioneel Afrikaans of Afrikaner-georiënteerd bekend is nie, hulle reeds op die jeug begin rig het.

Prof Steenkamp meen dus dat dit gebiedend noodsaaklik is dat daar verbeeldingryk en pro-aktief beplan word vir so 'n scenario soos geskets. Hoewel sending en evangelisasie altyd 'n opdrag bly en die daadwerklike aandag van die kerk verdien, moet 
die feit dat duisende jongmense jaarliks van die kerk vervreem raak vanweë die afwesigheid van die kerk in hulle wêreld, ook deeglik raakgesien word.

'n Verdere vraag is of die kerk nie een of ander vennootskap met die gemeenskap moet aangaan om sulke jongmense met verrykingsonderwys te begelei nie. Kan die kerk byvoorbeeld afsydig bly wanneer ' $n$ behoefte aan godsdienstige, sedelike en kulturele vorming by hierdie jeug blyk? Die ou Christelik-nasionale onderwysbeleid het daarop neergekom dat die werk van die ouers en die kerk deur die staat oorgeneem is. Dit verander nou. Die kinders en die jeug word teruggee aan die ouers en die kerk. Die kerk sal nie alleen die kerk se posisie in heroorweging moet neem nie, maar die ouers ook moet toerus om hulle verantwoordelikheid teenoor hulle kinders na te kom.

'n Verdere saak wat hom interesseer, is die uitdagings wat 'n veranderende kommunikasie- en inligtingstegnologie vir die onderwys inhou in die sin dat sekere tradisionele onderrigmetodes en -uitgangspunte reeds in beginsel, indien nie in werklikheid nie, agterhaal is. Die hedendaagse gemeenskap is vinnig besig om deel te word van die "global village", 'n wêreldwye kommunikasie- en kennisgemeenskap. Die huidige regering is reeds verbind om Suid-Afrika by hierdie wêreldwye gemeenskap in te skakel en kommunikasietegnologie na afgesonderde gemeenskappe te bring.

Dit is deesdae vir 'n skoolkind makliker en vinniger om op die Internet na stof te gaan soek vir skoolprojekte as om in die skoolbiblioteek te gaan rondsnuffel. Internet bied toegang tot gerekenariseerde datastelsels en biblioteke. Groot ensiklopedieë, woordeboeke en naslaanwerke is relatief goedkoop op cd-rom-skywe beskikbaar en is in dié vorm ook meer gebruikersvriendelik. Die skoolbiblioteek verloor dus 'n groot deel van tradisionele funksionaliteit. Dit is goedkoper om in 'n goeie rekenaar met Internetskakeling te belê, en so iets open dan weer verdere moontlikhede.

Ongelukkig bring dit mee dat die boekkultuur besig is om te verdwyn. Kinders het nie meer die geduld om honderd of meer bladsye te lees nie. Daar moet vinnig en bondig by die punt uitgekom word. Dit raak ook die hedendaagse luisterkultuur. (Byvoorbeeld, ellelange preke het geen trefkrag meer nie). Onderrigmetodes wat hoofsaaklik uit diktaat en die volskryf van aantekeningboeke bestaan, behoort reeds tot die verlede. Die klem val nou op onderrig via selfontdekking en selfwerksaamheid. 
Die vraag is hoeveel onderwysers hierdie nuwe paradigma kan hanteer. Heropleiding van onderwysers het noodsaaklik geword, en dan nie as 'n eenmalige gebeurtenis nie. Vanweë die voortdurende en vinnige verandering van die wetenskap en tegnologie, het voortgaande of selfs heropleiding 'n vaste kenmerk van enige moderne onderwysstelsel geword.

Die vraag is of so iets suksesvol binne 'n gesentraliseerde onderwysstelsel bedryf kan word. Dit is in hierdie verband dat prof Steenkamp ruimte sien vir plaaslike insette. Skole of groepe van skole wat saamwerk, kan opgraderingsprogramme instel waarmee onderwysers tot nuwe kennis en kundighede kan vorder. Vennootskappe tussen skole kan selfs verder strek, naamlik die gesamentlike ontwikkeling van spesiale programme (byvoorbeeld telematiese onderrigprogramme) en stelsels. Daar kan ook gedink word aan vennootskappe met skole in ander dele van die land of in die buiteland met ooreenstemmende behoeftes of ter wille van kulturele kruisbestuiwing. In hierdie verband noem hy dat belowende kontak reeds met Nederlandse, Duitse en Switserse onderwyskundiges gemaak is. Hy is veral geïnteresseerd in die Duitse ervaring waar skoolstelsels van Wes- en Oos-Duitsland saamgevoeg word, omdat hy meen dat daar sekere parallelle met die huidige Suid-Afrikaanse ervaring behoort te wees.

'n Onderwystoergroep waarvan prof Steenkamp deel sal uitmaak, beplan trouens 'n reis later in 1999 na die meeste van hierdie lande op uitnodiging van instansies in Utrecht, Zwolle, Groningen, Von Humboldt Universiteit (Berlyn), asook die Duitse ministerie van onderwys. Skole wat bereid sal wees om as susterskole vir SuidAfrikaanse skole op te tree, sal geïdentifiseer word, met die oog op uitruiling van onderwyspersoneel en die gesamentlike hantering van heropleidingsprogramme.

\section{TEOLOGIE, DIE BEDIENING EN VOORTGESETTE PREDI- KANTSOPLEIDING}

Prof Lourens Steenkamp se akademiese rekord toon dat hy met gemak gestudeer het, selfs onder moeilike finansiële en persoonlike omstandighede. Ten spyte van sy wye aanleg en verskeie loopbaanmoontlikhede bly hy gefokus op sy primêre belangstelling, naamlik filosofie en teologie. 
Hy het by meer as een geleentheid die opmerking gemaak dat sy betrokkenheid by die Fakulteit Teologie 'n nuwe wending in sy akademiese belangstelling meegebring het. Waar dit vantevore hoofsaaklik in die rigting van die filosofie geneig het, het dit hierna 'n duidelike teologiese aksent gekry. In 1997 het hy ingeskryf het vir 'n doktorale studie in die vak Godsdiens- en Sendingwetenskap onder leiding van skrywer. Sy teologiese insig blyk uit die gemak waarmee hy by verskeie simposia en seminare as leier of voorsitter opgetree het. Hy het ook teologiese publikasies gelewer (waarvan 'n lys hierna aangebied word).

Sy primêre belangstelling was egter die Godsdiensfilosofie. Hy het hom daarvoor beywer dat hierdie subdissipline uiteindelik oor vier van die ses teologiese opleidingsjare aangebied word. Daarin sou dit hoofsaaklik gaan om filosofiese konteksskildering - die filosofies-kulturele agtergronde en konteks van die Westerse teologie. 'n Mens sou dit ook die godsdiensfilosofiese verkenning van die verinheemsingsgeskiedenis van die teologie in die Weste kon noem. Sodanige kennisname is belangrik vir die verstaan van kontemporêre en huidige teologiese posisies. Hieruit vloei voort sy belangstelling in die opkoms van die post-moderne paradigma in 'n poging om die hedendaagse konteks van die kerk te verstaan.

Die konteks van die kerke in Suid-Afrika is 'n verdere saak. Nie alleen is die polities-maatskaplike toneel vinnig aan die verander nie, maar blankes is ook skielik gekonfronteer met veranderings wat in Wes-Europa (insluitend Brittanje) en NoordAmerika plaasgevind het gedurende die jare van Suid-Afrikaanse isolasie. Pluralisering vind op feitlik elke lewensterrein plaas. Volksgenote verhuis op groot skaal oorsee, maar behou via die moderne kommunikasiemiddele steeds lewendige kontak met die mense tuis, selfs op daaglikse grondslag. Ons mense se horisonne verruim. Hulle is al beter ingelig, ook oor teologiese, etiese en lewensbeskoulike sake. Die tradisionele outoriteitsparadigma raak uitgedien. Lidmate begin vir hulleself dink.

Daar is ook by baie lidmate ontgogeling met die rol wat die Afrikaanse kerke in die vorige bestel gespeel het en wat beskou word as die kerke se onmag en onbeholpenheid in die huidige plurale bestel. Die reaksie hierop is uiteenlopend. Sommige lidmate en gemeentes trek hulle terug in ' $n$ soort askese waar die gemeentes soos virtuele kloosters begin funksioneer. Ander verskuif na charismatiese kerke waar eensydig gefo- 
kus word op die eie geloofs- (of dalk religieuse) belewenis gekoppel aan 'n populêre teologie met oënskynlik al die antwoorde. By ander is daar 'n grootskaalse rugkeer op die vorige waardebestel (met insluiting van kerk). Die patriotiese, amper godsdienstige band met land, volk en taal is in elk geval besig om te verslap. Die aftakeling van die Corpus Christianum het uiteindelik ook vir die Afrikaner werklikheid geword, sê hy. Laasgenoemde moet egter nie verstaan word as sekularisme, asof Afrikaners postreligieus word nie. Daar is steeds 'n groot behoefte aan religie, selfs by diegene wat nie meer kerklik is nie.

Nog 'n rede waarom baie lidmate hulle rug op die tradisionele Afrikaanse kerke keer, is volgens hom die soort teologie wat in hierdie kerke ontwikkel het en wat gekenmerk word deur 'n krisis oor eie identiteit, wese en rol. Enersyds wil dit kerklike teologie wees, maar andersyds streef dit ook na geloofwaardigheid en aanvaarding onder die wetenskappe. Teologiese dosente verbonde aan universiteite verkeer onder druk van 'n sisteem wat navorsing en publikasies eis en wat hulle in die hedendaagse wetenskapskultuur opneem. Die kritiese styl van 'n "wetenskaplike" teologie is dalk besig om die wonder van geloof en die geheimenis van God te erodeer. Dit is moontlik dat die post-kritiese naïwiteit waarop ons dikwels aanspraak maak, in die proses weggeslyt raak. Die soeke deesdae na 'n Hervormde spiritualiteit vind hy goed, maar vind dit tog raar dat die gesprek met "tipiese Hervormde” objektiwiteit en nugterheid gevoer word.

Daar is dus kommer dat die drang om vir teologie 'n staanplek onder die wetenskappe te verdien, daartoe kan lei dat die teologie 'n slagoffer word van die positiwistiese wetenskapskultuur.

Teen die agtergrond van bostaande het hy vir die doel van die studie waarmee hy tans besig is, begin om hom in die literatuur van Mircea Eliade, die bekende Romeense godsdiensfenomenoloog, te verdiep. Eliade se verstaan van godsdiens, heiligheid en die mite het hom gehelp om 'n nuwe waardering vir die wonder van geloof, vroomheid en die "liturgiese oomblik" te ontwikkel. Dit het egter ook nuwe vrae by hom opgeroep oor die moontlikheid om teologie "wetenskaplik" te beoefen en so 'n teologie vir die vorming van predikante aan te wend.

Oor die eise van die hedendaagse bediening voel hy tweeslagtig. Enersyds meen hy dat predikante aan sekere professionele kennis en vaardighede te kort skiet. As voor- 
beelde noem hy 'n onvermoë om te organiseer en te bestuur, rekenkundige onvermoë, onkunde in sake finansiële bestuur ensovoorts. Predikante is nie werklik hiervoor opgelei nie en is dikwels geneig om daarvan weg te skram. Agterna staan hulle verbaas as die gemeente finansieel agteruitgaan. Die teologiese opleiding moet syns insiens nader beweeg aan die eise van die praktyk en die gemeentelike situasie. Hier lê verder 'n braakveld vir die voortgesette opleiding en toerusting van predikante. Hy is selfs van oordeel dat spesialiste in die Fakulteit Ekonomiese en Bestuurswetenskappe genader kan word om toepaslike programme in samewerking met die Fakulteit Teologie te ontwikkel en aan te bied.

Aan die ander kant is hy bekommerd dat predikante al meer bestuurders of fasiliteerders word en die kuns van pastor verleer. Baie predikante is meer tuis met stelsels en in vergaderings as wat hulle met hulle eie lidmate is. Dit gaan nie net om die kuns en kompetensie van pastor nie. Dit gaan ook om pastorale bewoënheid, ja meer nog, om geloofsbewoënheid. Lidmate raak al meer op hulleself aangewese en ag dit dikwels nie eers meer nodig om die predikant in tye van krisis te nader nie.

In hierdie verband verwys hy ook na die "liggaammodel" wat sterk figureer het in die destydse verslag oor bedieningstrukture aan die Algemene Kerkvergadering. Vandag kyk hy met nuwe oë daarop terug en meen dat te veel daarvan gemaak is. Ja, die outoriteitsparadigma is besig om uit te faseer, maar vir die ware herder sal daar altyd plek in die kerk van Jesus Christus wees.

Laastens het hy vrae oor die effektiwiteit van die huidige stelsel van opsig oor predikante in die Hervormde Kerk. Hy meen dat dit te veel ruimte bied vir ontduiking van pligte en verantwoordelikhede aan die kant van die predikant. Hy is ten gunste van 'n meer direkte diens- en opsigverhouding tussen predikant en kerkraad en meen ook dat die Kerkorde so verander moet word dat dit duidelik is dat die kerkraad die "werkgewer" van die predikant is.

Oor voortgesette opleiding van predikante stem hy met diegene saam wat sê dat geen beroepspersoon vandag meer sonder voortgesette opleiding kan funksioneer nie. Die konteks en eise van die bediening verander voortdurend en die moontlikhede van opleidingstemas is haas onuitputlik. Tog voel hy dat die verkondiging (in die verskil- 
lende gestaltes daarvan) altyd op een of ander manier die fokuspunt daarvan moet uitmaak.

Ofskoon prof Lourens Steenkamp se loopbaan as dosent nou tot 'n einde gekom het, sal daar met belangstelling gelet word op sy voortgang op ander lewensterreine, veral in die kerk, en die uitleef van sy persoonlike akademiese belangstelling. Hy en sy eggenote word God se nabyheid en seën op hulle pad vorentoe toegewens.

\section{Nagraadse studie}

1983. Magister in filosofie (met lof). Titel van die verhandeling: "Die ontwerp van 'n metafisiese orde by die vroeë Griekse kosmoloë."

1987. DPhil (met lof). Titel van die proefskrif: "Die godsbegrip by Aristoteles."

\section{Publikasies}

\section{HERVORMDE TEOLOGIESE STUDIES}

1992. Sentrum vir Voortgesette Teologiese Toerusting, Fakulteit Teologie (Afdeling A), Universiteit van Pretoria. HTS 48, 463-476.

1994. Verskillende scenarios met die oog op privaat-kerkskool, staatsondersteunde - en staatskool in 'n veranderde onderwysbedeling. HTS 50, 330-344.

1995. Kerk onderweg na die een-en-twintigste eeu: 'n Kritiese besinning oor kerkwees in 'n veranderde konteks in Suid-Afrika. HTS 51, 604-622.

1996. Kerk en kultuur in 'n postmoderne samelewing. HTS 52, 746-764.

1997. Akademiese protokol in die teologiese wetenskap. HTS 53, 691-704.

1997. Belydenis: Objektiewe waarheid of eksistensiële uitdrukking van geloof? HTS 53, 1331-1356.

\section{Almanak}

1989. Ouderling Marthinus Pretorius. Almanak 83, 32.

1992. Sentrum vir Voortgesette Teologiese Toerusting: Voortgesette toerusting van diensdoende predikante en praktiese opleiding van teologiese studente. Almanak $86,24-27$. 


\section{Studieverslae aan die Kommissie van die Algemene Kerkvergadering}

1983. Bedieningstrukture (as medewerker).

1993. Onderwys en opvoeding - memorandum oor die onderwysmodelle vir die toekoms.

\section{Die Hervormer}

1981, Desember. Redaksioneel: Kruispunte en keuses in 'n krisistyd.

1982, Oktober. Briewe: Staan self agter die deur!

1982, Oktober. Hervorm na die eise van die Woord of sterf.

1983, Januarie. Aanvaarding van die gestremde het gesonder gemeenskap tot gevolg.

1984, Augustus. Fokus op die media: Media moet hom weerhou van polariserende beriggewing.

1984, September. Armes armer en rykes ryker?

1984, November. Fokus op die media: Word kerk verkwalik vir standpunt oor omstrede wette?

1985, Januarie. Fokus op die media: Bonusobligasies; melkkulture ... en perdewedrenne.

1985, Januarie. Jong Hervormer se kategeserubriek: Gebed, 'n gesprek met ons hemelse Vader.

1985, Februarie. Fokus op die media: Brief aan predikante ook in die openbare pers gerapporteer met moontlike kontraproduktiewe gevolge.

1985, Februarie. Jong Hervormer se kategeserubriek: Gebed - as die Vader weet wat ons nodig het, hoekom vra ons Hom dan?

1985, Maart. Fokus op die media: Dit kan ook met ons gebeur!

1985, Maart. Jong Hervormer se kategeserubriek: Gebed - hoe behoort ons te bid?

1985, Mei. Jong Hervormer se kategeserubriek: Aanhef van Jesus se gebed (Matt 6:9).

1985, Junie. Fokus op die media: Venyn, wat net groei en groei.

1985, Junie. Jong Hervormer se kategeserubriek: Eerste bede van Jesus se gebed.

1985, Julie. Jong Hervormer se kategeserubriek: Tweede bede van die Tien Gebooie. 
1985. Julie. In en om die kerk: Een se nood ... is almal se nood. Ek is jammer ... jy is afgedank.

1985, Augustus. Jong Hervormer se kategeserubriek: Derde bede van die Tien Gebooie.

1985, September. Fokus op die media: Verbruiker, prysstygings en die reg om te eet.

1985, September. Jong Hervormer se kategeserubriek: Die vierde bede van Jesus se gebed - die vierde bede.

1985, Oktober. Fokus op die media: Revolusie mag nie ontwikkel tot nuwe regering nie.

1985, Oktober. Jong Hervormer se kategeserubriek: Die drie laaste bedes van Jesus se gebed.

1985, November. Jong Hervormer se kategeserubriek: Die drie laaste bedes van Jesus se gebed.

1985, Desember. Jong Hervormer se kategeserubriek: Die afsluiting van Jesus se gebed.

1986, Januarie. Fokus op die media: Wanneer sal ons leer om die televisie doeltreffend te gebruik?

1986, Mei. Fokus op die media: Ons kan nie anders as om te protesteer.

1986, Desember. In en om die kerk: Was 1986 'n gelukkige keuse as Jaar van die Gestremde?

1987, April. Fokus op die media: Vrae wat rondom die Menloparkse histerie gevra behoort te word.

1987, Mei. Jong Hervormer - jaartema: Die jongmens as deel van die gesin (5) - Kom ons praat met mekaar.

1987, Mei. Jong Hervormer se Bybelstudie: Praat deur die Woord met God en jou gesinsgenote.

1987, Oktober. Fokus op die media: Ons staan skuldig teenoor ons oumense en kinders.

1988, Julie. Fokus op die media: Gebeure rondom die afdanking van die SAUK se Direkteur-Generaal laat smaak in die mond.

1988, Oktober. Fokus op die media: Geld die etiese eis nog?

1988, Oktober. 'Smart in pastorie: Wyle Lileen Pienaar.

1989, Januarie. Redaksioneel: Toekoms vir ons kinders. 
1989, Maart. 500 Besin saam oor huwelik en gesin.

1989, Maart. Kerk-Aktueel: Kerk mag nie swyg oor die kanker van hebsug en korrupsie nie.

1989, April. Kerk-Aktueel: Ons arbeid - wie nie wil werk nie, moet ook nie eet nie.

1989, Mei. Kerk-Aktueel: Rykdom van die gebedslewe voed ons geloof.

1989, Augustus. Is daar steeds ' $n$ lewende wederkomsverwagting by ons lidmate?

1990, Februarie. Bring die neëntiger jare hoop ... hoop waarop en waarheen?

1990, Februarie. Redaksioneel: Kerk en die politici behoort steeds te praat.

1990, Maart. Redaksioneel: Daar is rede tot kommer oor ons leeskultuur.

1990, Maart. Redaksioneel: Gelukwense aan die redakteur van Konteks: Dr Paul de Beer.

1990, Maart. Redaksioneel: Kerk in die stad.

1990, 15 Julie. Aangename verrassing tydens SVTT-kursus.

1990, 1 Augustus. Redaksioneel: Vorming van 'n reggeaarde bedienaar van die Woord.

1991, 15 Mei. Kommentaar: Simptoom van oppervlakkigheid in ons godsdiens en samelewing.

1992, 1 Mei. Geheimenis van die werk van die Heilige Gees.

1992, 1 Mei. Kerk se belang by opvoeding en onderwys.

1992, 15 Maart. Hedendaagse Epikurese lewensgevoel.

1993, 15 Februarie. Kommentaar: Een onderwysdepartement - 'n paar kritiese vrae.

1993, 1 April. Redaksioneel: Owerheid se plig om orde in stand te hou.

1993, 15 April. Mense en gebeure in ons kerk se lewe: Bedrywige jaar lê vir Kital voor.

1993, 15 April. Werkswinkel oor kerkskole.

1993, 15 Mei. Kerk moet diep nadink oor die onderwys.

1993, 15 Augustus. Mense en gebeure in ons Kerk se lewe: SVTT dien kerk en gemeenskap oor wye terrein.

1993, 1 September. Onderwyskongres in vooruitsig gestel.

1993, 15 Oktober. As 'n kerk kwyn, is dit omdat hy sy apostolaat verwaarloos. 
1993, 1 November. Afrikaanse kerke gaan saam besin oor onderwys.

1993, 1 November. Dank teenoor onderwysers.

1993, 1 Desember. Kommentaar: Godsdiensregte in 'n akte van menseregte. Integriteit van owerheid sal deurslag moet gee.

1994, 15 Maart. Kommentaar: Kommunisme is dood - lank lewe die Kommunisme.

1994, 1 April. Kommentaar: Geweldskultuur moet gekeer word.

1994, 15 April. Bybelskool: 'n Unieke geleentheid.

1994, 15 Junie. Geslaagde Bybelskool ... daar is nog geleentheid.

1994, 1 Augustus. Kommentaar: Eis om grondverdeling - 'n emosionele saak met religieuse ondertone.

1994, 1 September. Teologiese fakulteit wil werk en diens beter bekendstel.

1994, 15 September. Konferensie oor selfmoord by kinders.

1994, 1 Desember. Antwoorde op nuwe steeds vanuit perspektief van eie tradisie. Roeping van die Kerk in Suid-Afrika vandag.

1995, 1 Augustus. Kommentaar: Terugblik op die 64ste Algemene Kerkvergadering.

1996, 15 Februarie. Nuusaktueel: Konsep-witskrif oor onderwys.

1996, 15 Maart. Mense en gebeure in ons kerk: Studiewerk in kerk word bespreek.

1996, 1 April. Kerk en kultuur: Voortgesette Teologiese Toerusting vir Predikante 1996.

1996, 15 September. Bedreigings en geleenthede in die onderwys.

1996, 15 Oktober. In diepte ... : Onderwys op pad na die een en twintigste eeu - krisis of geleentheid?

1996, 15 Desember. Nuwe rektor van UP positief oor die teologiese fakulteit.

1997, 1 Julie. Kerk en teologie: Enkele opmerkings oor tradisionele godsdienstigheid.

1998, 15 Julie. Onderwysstaking afgeweer - maar krisis duur voort.

1998, 1 Augustus. Dit is my standpunt: Strategiese beplanning noodsaaklik vir skole.

\section{Konteks}

1997, November. Godsdiensfilosofie.

1997, November. Sentrum vir Teologiese Navorsing en Toerusting. 